\title{
CHALLENGES AND POSSIBILITIES OF REMOTE EDUCATION IN TIMES OF COVID-19: PERCEPTIONS OF BRAZILIAN TEACHERS ABOUT THE EFFECTS ON RELATIONSHIPS WITH STUDENTS AND FAMILIES
}

\author{
Lorena Machado do Nascimento ${ }^{1}$ \\ Maria dos Remédios Lima Silva ${ }^{2}$ \\ Fernanda Fátima Cofferri ${ }^{3}$ \\ Bettina Steren dos Santos ${ }^{4}$
}

\begin{abstract}
This article aims to analyze teachers' perceptions about the implementation of remote education and the effects on relationships with students and families during the Covid-19 pandemic. The research was conducted during 2020, through an electronic questionnaire and answers from 178 teachers were analyzed. The reflections presented in this study are based on the work of the theorists Morin and Viveret, Saviani and Galvão, González Rey, Ganda and Boruchovitch, Santos, among others. The analysis was conducted according to the principles of the Content Analysis methodology (Bardin, 2011). The results expressed in the discourses demonstrated impacts on the relations between the actors that generate this remote teaching scenario, including teachers, students and families. Another aspect found was that, often, the importance of quality in these relationships, and in the routine of daily life, goes unnoticed, but has a strong link with the quality of learning. Thus, it is believed that the experience of remote teaching in times of pandemic can serve as a significant Post-Pandemic learning opportunity.
\end{abstract}

Keywords: teaching; subjectivity; remote education; Covid-19

1 Pontifícia Universidade Católica do Rio Grande do Sul, Porto Alegre, Brasil. Contacto: lorena.nascimento@edu.pucrs.br

2 Pontifícia Universidade Católica do Rio Grande do Sul, Porto Alegre, Brasil. Contacto: maria. remédios@edu.pucrs.br

3 Pontifícia Universidade Católica do Rio Grande do Sul, Porto Alegre, Brasil. Contacto: fernanda.cofferri@edu.pucrs.br

4 Pontifícia Universidade Católica do Rio Grande do Sul, Porto Alegre, Brasil. Contacto: bettina@pucrs.br 


\title{
DESAFÍOS Y POSIBILIDADES PARA LA EDUCACIÓN A DISTANCIA EN TIEMPOS DE COVID-19: PERCEPCIONES DE LOS PROFESORES BRASILEÑOS SOBRE LOS EFECTOS EN LAS RELACIONES INTERPERSONALES ENTRE ESTUDIANTES Y FAMILIAS
}

\begin{abstract}
RESUMEN
Este artículo tuvo como objetivo analizar las percepciones de los docentes sobre la implementación de la enseñanza remota y los efectos en las relaciones con estudiantes y familias durante la pandemia Covid-19. La encuesta se realizó durante 2020, a través de un cuestionario electrónico, en el que se analizaron las respuestas de 178 docentes. Teóricos como Morin y Viveret, Saviani y Galvão, González Rey, Ganda y Boruchovitch, Santos, entre otros, apoyaron las reflexiones presentadas en este estudio. El análisis de los registros se realizó, por medio de los principios de la metodología de Análisis de Contenido (Bardin, 2011). Los resultados expresados en los discursos producidos mostraron impactos en las relaciones entre los actores que conforman este escenario de enseñanza a distancia, incluidos docentes, alumnos y familias. Otra reflexión producida fue que, muchas veces, la importancia de la calidad de estas relaciones, en el día a día, pasa desapercibida, pero está fuertemente relacionada con la calidad del aprendizaje. Por lo tanto, se cree que la experiencia del proceso de enseñanza y aprendizaje remoto, en tiempos de pandemia, puede servir como una oportunidad para un aprendizaje significativo en Post-pandemia.
\end{abstract}

Palabras clave: trabajo docente; subjetividad; enseñanza remota; Covid-19 


\section{Introduction}

This article is part of a broader study, developed by a research group of a Brazilian Community University located in the Southern Region of Brazil, which investigates topics in the area of teacher's education and biopsychosocial aspects in educational contexts. This article aims to analyze teachers' perceptions about the implementation of remote education and the effects on relationships with students and families during the Covid-19 pandemic. Given the pandemic context, teachers working in Public and Private Schools in Brazil participated in our research and, from some reports we elaborated this text to dialogue about some perspectives about emergency remote education implemented in Public and Private Schools in Brazil during the Covid-19 pandemic. The central subject refers to the challenges and possibilities of remote Brazilian teaching.

For a comprehensive understanding of the period of time we are talking about it is relevant to mention some data from the Pan American Health Organization (PAHO) and the World Health Organization (WHO) that point to January 30, 2020 as the beginning of the outbreak of Covid-19 disease, caused by the new coronavirus (Sars-Cov-2). On March 11, 2020, Covid-19 was identified by the WHO as a pandemic. From there, humanity has experienced economic, sanitary, social and educational instability that, in countries such as Brazil, have no expiration date. This is because by mid-June 2021, a year and a half after the onset of the pandemic, more than 450.000 deaths and 16 million infected had been recorded.

To this day, Brazilian society has been facing turbulent and uncertain days. At times, with the arrival of vaccines, it seems to prevail hope for better ${ }^{5}$ days. However, the feelings of fear and insecurity return to the numbers of infected and dead, as has been commented before.

5 At the time this article was written, teachers and basic education workers in Brazil were being vaccinated in most Brazilian States. Source: https://gl.globo.com/bemestar/vacina/ noticia/2021/05/28/ ministerio-da-saude-vacina-educacao-nao-prioritarios.ghtml 
According to the Ministry of Education (MEC, 2020), in all Brazilian states, the suspension of classes was carried out to restrain the progress of the pandemic and the spread of the new coronavirus. Worldwide, according to data from the United Nations Educational, Science and Culture Organization (UNESCO), which monitors the impacts of the pandemic on education, "19l countries have determined the closure of schools and universities". This decision covers approximately " 1.6 billion children and young people, which corresponds to $90,2 \%$ of all students".

When it comes to Brazil, there is another worrying factor to be addressed. According to data from the Census of Basic education $^{6}$, (Brasil, 2020) in 2020, 47.295.294 million admissions were registered in the 179.500 primary schools in Brazil, about 579.000 fewer admissions compared to 2019, which corresponds to a reduction of $1,2 \%$ in total, since 2019 , when the number of admissions in public and private basic education was 47.874.246. These data indicate a significant drop in the number of enrollment in basic education, which represents an atypical reality in which the basic education gap may be even greater than in other challenging times. In this uncertain scenario, we can mention some elements that will be discussed about teaching in the pandemic, namely: adaptations in curriculum organization, pedagogical practice and routine of entire families. It is also noteworthy that the measures adopted to promote remote education can transform dialogue and/or the creation of new forms of affective interaction between teachers, family members and students. However, as human beings, our human peculiarities and the "self and being" in the world became susceptible to impacts at this historic moment and we may know the proportion of these changes, in the long run. Thus, because we understand that education is involved as a whole, we will address some topics pertinent to this problem.

6 Basic Education: from 4 (four) to 17 (seventeen) years old, organized as follows: a) pre-school; b) elementary school; c) high school; (Writing by Law No. 12,796, 2013) - LDB - Laws of guidelines and bases of education - LDB is the most important Brazilian law that refers to education, regulates the educational system (public or private) of Brazil. Accessed: June 6 2021. Available from: L9394 (planalto.gov.br) 


\section{Theoretical Framework}

To understand the process of reconstruction of the affected subjects, due to the changes implemented in the school context during the pandemic, the work of different authors was reviewed to analyze the conditions, relationships, emotions and subjective configurations elaborated by them, as well as some studies that corroborate the data found in this study.

According to Hermann (2020), there is a phenomenological dimension in the pandemic as a fact that brings the unusual, the intimidating, because it shakes the current order and suppresses usual responses, dictating other ways of organizing life and relationship with others, in addition to extraordinary measures, many of them only seen in states of war. In most Brazilian schools, adaptation to online teaching and/or remote teaching was implemented and "learning and teaching" remotely was a new situation for teachers and students.

As we have already commented, social isolation, necessary to restrain the advance of the Covid-19 pandemic, has caused unimaginable changes and reminds us of the ephemerality of our existence. Education, this course of lifelong learning, has also been affected by the impacts of isolation. It becomes a challenge to deal with the specificities and influences that isolation causes in educational routines, teaching and learning processes and social relations between teachers, students and families involved.

It was in this scenario that schools started to use emergency remote education, which is different from distance education, as this is characterized as a consolidated modality. The above corroborates Saviani and Galvão (2021) the expression "remote teaching" began to be used as an alternative in distance education $(\mathrm{EaD})$. This is because the EaD already occurs, coexisting with faceto-face education as a distinct modality, offered regularly. On the other hand, remote education is seen as an exceptional substitute in this period of pandemic, in which face-to-face education is suspended. 
Thus, it was crucial to adapt to social isolation, in order to contain the dissemination of Covid-19. In addition to other people, students, teachers and family members had to adapt to the individual and family environment to keep their routines close to those they experienced before the pandemic. This was and remains a challenge because what was supposed to be provisional became continuous and remote teaching lasted throughout the year 2020 in most Brazilian Schools and Universities.

In addition, Brazilian laws such as the Federal Constitution (1988) the Law of Guidelines and Bases of Education (LDB) support the role of the family in the purpose of educating their children in partnership with the State. Therefore, government regulation, through the Mystery of Education (MEC), and the National Council of Education (NCE), also regulates and complement the right to education to all Brazilians. In this sense, it helps us to reflect on the educational context in the midst of the Pandemic. According to Santos (2020), the entire quarantine is unfair and unequal, because there always are those who are not able to face such challenges. In turn, Monteiro (2020) contributes by asking pertinent questions about this pandemic scenario regarding education as possibilities and resignification.

Nóvoa and Alvim (2021) point out that "the school has always had two main missions: to get students to learn to study and work through knowledge; through the relationship, students learn to live with one another" (p.13). Schmidt (2018) adds "community life meets human nature by fulfilling the permanent needs of conviviality and meaningful connections" (p. 10).

We know that, so far, there are no effective evaluation processes for this emergency modality, but it is noticeable that, with all the difficulties presented (difficulties with technological, financial, family, emotional and physical resources) the standard of learning and the development of students are compromised. And the social role of the school is also shaken, just as the relationship of students with the school, their teachers and knowledge is shaken. That is: 
We need to get out of this crisis with a clear project for the future of education, knowing that there are many different paths to be followed, but always maintaining the defense of education as a public and common good and recognizing the need for a profound transformation to better the system (Nóvoa \& Alvim, 2021, p. 16).

Basic education is perhaps the most affected group with this new reality, because most children and adolescents with little autonomy need the support of families and/or caregivers to attend classes and perform tasks using technological resources. In an individualized and autonomous perspective, they need to manage school activities alone without the direct support of their teachers.

This new freedom of learning, defended by some movements of unschooling, and criticism of the structure of the school, care little about the condition of students and their contexts for such learning, especially that of Public School, and according to Nóvoa and Alvim provides the "corrosion of social ties and pedagogical ties between teachers and students" (2021, p. 19).

According to Ganda and Boruchovitch (2018), in addition to personal beliefs, motivation and the use of learning strategies, the process of self-regulation is permeated by emotions and feelings, which manifest themselves (before, during and after) in the performance of a given task. To these authors, the regulation of emotions plays a fundamental role in the execution of these activities, which start from a process of recognition, evaluation and search for strategies of emotional responses. But often the ways used by students encompass the suppression of emotion, distraction activities, and, only in the end, the search for help.

Regarding the motivational processes experienced by the subjects, Ganda and Boruchovitch (2018) state that "emotions can affect learning in a positive or negative sense, depending on its intensity, student characteristics, cognitive and metacognitive strategies known and used by them and even the cultural context in which they are inserted" (p. 73). From the perspective of 
subjective aspects, González Rey (2017) understands subjectivity as a complex process that recognizes the individual and its history, culture and singular characteristics, in the relationship between the individual and social subject. Thus, social isolation is understood as a moment that requires the analysis and understanding of human subjectivities, seeking answers to deal with what Hermann (2020) called the phenomenological dimension of the pandemic, since in secureness and ignorance of a fact without warning, as well as a crisis, cause feelings of restlessness, disturbance and existential insecurity.

The authors Morin and Viveret (2013) have written about times of crisis, such as the one we currently live in. According to the authors, moments of crisis are inevitable. With them, there are challenges and opportunities that impact on various aspects of human and social life. Marchesi (2008) and Mosquera and Stöbaus (2006) indicate that affectivity is a fundamental part of the teaching and learning process, especially at times of social isolation, in which social relations are more uncertain.

The return to the old normality is something with no expected date, at least in Brazil. At this moment, it is worth thinking that there is still a moment of critical disjunction that may involve destructive aspects, but is also fundamentally a source of rebirth (Morin \& Viveret, 2013). The discussions here lead to a critical reflection where it is not possible to fantasize about a rosy world and to think that all problems will cease. Just as there exist the reality of pandemic chaos, configured by various characteristics, causes, effects and peculiarities, there is another side that points in the direction of what seems unlikely, which reflects the worldwide reorganization leaving behind the pandemic and the impacts of social isolation on the lives of teachers, students and entire families living this reality. It is one of the most significant historical moments for this generation, which has demanded a "reinvention", because life in society is full of challenges and discussing such events and their effects on human subjectivity is one of the paths pointed out in this research. 


\section{Methodology}

\section{Characterization of the study}

This research was developed from a qualitative methodological perspective. It is based on the theoretical perspective of Flick: "qualitative research is oriented to the analysis of concrete cases in their temporal and local particularity, starting from the expressions and activities of people in their local contexts" $(2009$, p. 28). In this sense, Triviños (1987) corroborates this approach, when he says: "One of the great postulates of qualitative research is its preferential attention for the assumptions that serve as the basis for people's lives". (p. 130).

Qualitative research, according to Flick (2009) differs from quantitative research, because it seeks to analyze and interpret the data in all its complexity, respecting the characteristics and reality of the subjects involved in all its context. As well as, in this type of research, "the interpretation of phenomena and the attribution of meanings are fundamental in the qualitative research process. It does not require the use of statistical methods and techniques" (Leal, 2006, p. 17).

The objectives are exploratory, because this work aims to "provide greater familiarity with the problem in order to make it explicit or to build hypotheses" (Leal, 2006, p. 19). It is not characterized by being a rigid method, but a set of possibilities to give meaning to content and enable the researchers to increase their knowledge about a given problem.

\section{Data analysis technique}

For the analysis of the data produced, we used principles of content analysis according to Laurence Bardin (2011). For this author, in the initial phase of this process, the corpus of analysis was organized in the following stages:

- Reading all the material and identify the information samples; 
- Encoding the material, with colors or numbers, to facilitate its access;

- Separating the content into elements called units of analysis that will allow the contents to be separated and regroup them in categories;

- Categorizing the units of analysis;

- Describing categories;

- Interpreting the results.

This study is a fragment of the research already mentioned including the analysis of the following questions: What impacts do you perceive in the relationship between teachers and students in this new context? How do you perceive the students in this context? Have you had contact with parents, mothers and/or guardians of students? How are parents and/or guardians offering support to their children during their activities? Are you communicating with the students? How?

We used the Category Content Analysis (CCA) to analyze the narratives making interpretations and reflections about the conditions of production of the texts, and then reach the stage of the conclusion of the categories, and after a critical, reflexive and reconstructive reading of the units of analysis, three categories emerged: Human relations and construction of subjectivities; Support and family routine in the face of school demands; and impacts on the relationship/interaction between teachers and students. These categories will be presented in the next section.

\section{Instrument for data collection}

The instrument used for data collection was an online questionnaire, due to the need for social isolation that the pandemic required. Gil remarks that the questionnaire has the "aim of knowing opinions, beliefs, feelings, interests, expectations, situations experienced" (2008, p. 128). Also, according to the author it is a technique used to collect information from reality, which can make up a more or less high number of questions, makes it possible to reach a large number of people, since the questionnaire can be sent in writing or 
digital means to the research subjects and allows people to answer it at the time they deem most convenient (Gil, 2008).

The questionnaire was organized on the digital platform of Google Forms, which included 25 questions, being: 5 questions of characterization of the subjects; a section with 17 questions directed to investigate who adopted remote emergency education; a section with 3 questions oriented to subjects who did not adhere to emergency remote education.

\section{Sample characterization}

The research subjects were defined in a mixed and flexible way (Flick, 2009) with teachers working in any educational level during emergency remote education in the Covid-19 pandemic, because according to Flick (2009) this type of selection is defined based on the needs of the research and conditions of the real context of the research. The questionnaire was sent via e-mail to several groups of teachers in different schools and educational networks. After agreeing to accept the Free and Informed Consent Form (TCLE), which guaranteed anonymity, the questionnaire was released to be filled out.

The sample was selected for "convenience where the elements are chosen because they are accessible, more articulated or easier to be evaluated" (Leal, 2006, p. 74). In this article, we used the answers of teachers working in early childhood education, elementary school and high school, levels that characterize Brazilian basic education totaling 178 respondents.

The social information collected characterizes the research subjects and was organized graphically in order to illustrate the sample. As shown in Table 1, the majority of teachers work in public schools $(74,8 \%)$, and $40,1 \%$ work in an elementary school (Table 2). 
Table 1.

Type of institution teachers work for

\begin{tabular}{lc}
\hline Type of Institution & Percentage of subjects \\
\hline Public & $74,8 \%$ \\
Private & $20,2 \%$ \\
Associative/community & $1 \%$ \\
More than one sector & $4 \%$ \\
\hline
\end{tabular}

SOURCE: Built by the authors (2020)

Historically, the curricular structure, contexts and pedagogical practices of the public school are questioned and criticized, however this institution is responsible for the care of the majority of Brazilian students in basic education, as it is shown in these two graphs.

Table 2.

Educational level where teachers work on

\begin{tabular}{lc}
\hline Educational Level Teachers Work & Percentage of subjects \\
\hline Early Childhood Education & $21,9 \%$ \\
Elementary School & $43,6 \%$ \\
Middle School & $7,5 \%$ \\
Young Adults Education & $1,8 \%$ \\
Specialized Educational Service & $1,4 \%$ \\
More than one sector & $23,8 \%$ \\
\hline
\end{tabular}

SOURCE: Built by the authors (2020)

Regarding the period of time teachers have been working - an important factor to analyze the experience of professionals in the educational context- most of them report more than 10 years in education (51\%), with $36,6 \%$ over 15 years (Table 3 ).

Table 3.

Years working in teaching

\begin{tabular}{lc}
\hline Years working in education & Percentage of subjects \\
\hline More than 15 years & $36,6 \%$ \\
Between 10 and 15 years & $14,4 \%$ \\
Between 5 and 10 years & $26,2 \%$ \\
Up to 5 years & $21,8 \%$ \\
Didn't answer & $1 \%$ \\
\hline
\end{tabular}

SOURCE: Built by the authors (2020) 
The data suggest that the profile of respondents is strongly characterized by teachers of basic education in public institutions who have been working for more than 10 years.

\section{Results and Discussions}

The results of teachers' perceptions about remote education who answered the questionnaire will be presented below. Three categories were organized: human relations and construction of subjectivities; family support in school activities during the pandemic; and impacts on interaction between teachers and students. Such categories will be discussed below. It is also registered that both compose an experienced process, not being isolated narratives, and draw a sequence between data and theories.

\section{Human relations and subjectivities construction}

The analysis presented here will be regarding teacher's perceptions about students in the context of remote teaching, from the category human relations and construction of subjectivities. The context of school shutdown and the emergency need for the adoption of new methodologies — such as remote teaching to ensure the continuity of the work of educators- generated an unpredictable educational reconfiguration and teaching and learning processes. And this reconfiguration is generating important consequences in the emotional and psychological context of students in the face of such an unstable context and unpredictable future, as well as impacts on their learning, and the increase in inequality between public and private schools.

According to the National Institute of Educational Studies and Research Anísio Teixeira- INEP (Brasil, 2021) in 2020, 47.3 million enrollments were counted in the 179.500 Primary Education Schools in Brazil, about half of the students enrolled are attended by Brazilian Municipalities $(48,4 \%)$ and the private network has a stake of $18,6 \%$. Already a survey conducted in July 2020 by the DataSenado Institute pointed out that: 
$26 \%$ of households with students taking remote classes in the public network do not have internet. In the private network, the percentage drops to $4 \%$. Also according to the results, cell phones (64\%) and computers (24\%) are the most used equipment to access study materials. (Senate Agency, 2020)

These changes and challenges brought by social withdrawal have generated impacts in all areas of education. Facing a very challenging reality that needs to be better understood in its different dimensions. Therefore, identifying the emotions that emerge in this crisis scenario is an important tool for taking actions.

When teachers were asked "How do you perceive the students in this context?" they have presented several reports, but the majority (55\%) highlighted emotional aspects such as apathy, anxiety, helplessness, insecurity and lack of motivation, as we can observe in the following excerpts:

Very helpless. With more difficulties than usual (P 29).

Lost... in need of the affection that the teacher gives them when teaching (P 42).

With many organizational difficulties, compliance with activities in addition to less motivation to study (P 76).

Apathetic, unsure (P 90).

Anxious, sad, nostalgic (P 103).

The students are very confused and have learning difficulties. They can't have a study routine (P 121).

Too many difficulties and a huge anxiety (P 144).

These data corroborate a survey conducted by the State People's Committee for the Monitoring of Educational Crisis, in Rio Grande do Sul, with Mothers/Fathers/Guardians of students from the municipal, state and private networks of Porto Alegre, between 
July and August 2020, where the majority agrees or agrees in part $(72,2 \%)$ that your child is in a different mood - sad, angry, anxious, depressed. When we look only at public school students, this rate rises to $85,6 \%$. (State People's Committee for the Monitoring of Educational Crisis, 2020).

Some teachers noted there are students without family support, with technological difficulties and without access to technology to be able to follow classes, either from a computer or mobile phone, or having access to the internet at home:

I realize that many children cannot organize their activities at home, and many also do not have the support of their families, mainly because the parents are working and do not have time (P 38).

Out of context, because many do not have access to virtual media and many families are working normally, children end up being on their own (P 74).

Our students are a little lost, some manage to organize and deliver their activities. Unfortunately, many students live in places without the minimum conditions to study and do not have access to technological means, which makes it much more difficult (P 82).

The inequality that already exists became even more glaring. In addition to access to technology, access to food, health and culture was an issue too (P 133).

These answers show difficulties among the population most affected by even deeper inequalities, because, unlike the middle class, these families could not keep their jobs in a home office, nor can they provide adequate material settings for their children's remote classes. In the aforementioned research (State People's Committee for The Monitoring of Educational Crisis, 2020 s/p.), parents/guardians reported the greatest barriers faced by their children in remote classes. $20 \%$ say it is the limited computer availability; $17 \%$ report difficulty in understanding and accessing 
virtual class environments; $11 \%$ report internet issues; $10 \%$ say they don't have a device/computer; $6 \%$ indicate lack of space/lighting at home and $2 \%$ report lack of food.

With the sudden confinement in their homes, students face in different ways the difficulties mentioned above. And emotions as anxiety, sadness, anguish, discouragement, lack of interest, loneliness, will produce their own ways of dealing with each of the adversities and in this way they will (re)build on their subjectivities, which according to González Rey "subjectivity arises when emotion becomes sensitive to symbolic memories, allowing people to build the world in which they live, and not simply to adapt to it" (2017, p. 213).

In this sense, teachers also pointed out, in their answers, that despite demotivation, students presented, at a certain point, commitment to the study, trying to do their best, despite everything. And they add that the lack of interaction with their peers, not only in school, which has been the greatest difficulty in this process, is disruptively faced. In this way, we observe the following answers:

They are striving to adapt and perform this demand (P 14).

The students, the majority of them, are in great difficulty. They cannot interact and few have the tools to do so (P 17).

I suffer for them. I try to follow the curriculum and value the area of knowledge that I teach, but it is very difficult... This is no time to worry about subordinate sentences, equations, continental drift, acids and bases... It's time to look around and see that our world model collapses through a virus. It is almost dystopian to imagine that work and academic performance have been a priority instead of the sanity and quality of life of teachers and students... (P 19).

I understand that like teachers, they are also in uncertainty, anguish and, why not, with their difficulties in adapting to this new format of teaching. We should not overcharge ourselves (both sides) (P182). 
As teachers, we perceive a mutual understanding, we recognize the unfavorable conditions, in which everyone is exposed. Therefore, the subjects are able to experience an individual, reflexive and critical condition, but also are able to configure the responsibility that each one has in the organization and action in the different social contexts that they perform. Thus, emotion is understood beyond natural responses to events, but as a product of subjective senses and configurations of the current spaces of human life (González Rey, 2017).

The pandemic has generated numerous social challenges, but education is certainly one of the most impacted sectors. And the main challenge is to ensure the continuity of learning processes with collaborative practices between subjects, using technologies, in addition to a functional conception.

Researching, prototyping and testing of new educational models in a participatory and collaborative way, supported by public policies, subsidies, trained professionals and guarantee of equal access to students are paths that prove to be fundamental for the present and the future of Education and that emerge even more incisively due to the COVID-19 pandemic (Grandisoli \& Jacobi, 2020, p.03).

Thinking about education from a human perspective, in which different subjects coexist, relate and interfere in the representations of sense and meanings produced individually, but that affect the development of the collective.

The impacts in this category were expressed in the narratives of the research participants, when they refer to the pandemic scenario as a sensitive reality and they indicate that they feel and perceive how the socio-emotional dimension of the students have been affected. This evidence is permeated by a mixture of anxieties, fears, loneliness, insecurity and sometimes lack of meaning to studying.

The subject emerges in the exercise of their singular elaboration of thoughts in the face of what has been experienced. 
It is in this exercise, "subjectively dynamic, that the development of the possibilities of rupture with institutions gains strength" (González Rey, 2017, p. 48).

Experiences have become a constant challenge to confront on a daily basis not as the intention to get used to, but as a possibility to be resilient and learn from the available alternatives, in an aim at contributing to the education of subjects, who felt sensitive to the pain of the other or with the loss of family members, acquaintances, or even the number of deaths computed by the national and international media. Imbued with the feeling of empathy, in the midst of the crisis, students missed their mates who did not participate in online classes because they did not have access to technology. It was an opportune space to see other realities, even without leaving home.

\section{Family support in school activities during the pandemic}

According to the Magna Law that governs Brazil, the Federal Constitution (1988), Article 250 deals with the importance of the Family in Education together with the State. In these terms, it is expressed: "Education, the right of all and the duty of the State and the family, will be promoted and encouraged with the collaboration of society, aiming at the full development of the person, their preparation for the exercise of citizenship and their qualification for work". This task of the family has received unmatched visibility during the pandemic by Covid-19 in the most diverse social realities.

From the massive schools shutdown in mid-March, due to the pandemic chaos, the Ministry of Education (MEC), on March, 17th 2020, "provides for the replacement of classroom classes by classes in digital media for the duration of the pandemic situation of the New Coronavirus - COVID-19". The following month (April/2020), the National Council of Education (NCE) established guidelines to guide schools during the coronavirus pandemic. The opinion of elementary school early year as it goes: 
It is suggested that the schools guide families with practical and structured instructions to monitor the response of activities by children. However, the solutions proposed by the networks should not assume that "family mediators" replace the teacher's activity. The proposed non-face-to-face activities should delimit the role of adults living with students at home and guide them to organize a daily routine (BRASIL, 2020, no cover page).

It is a consensus that the role of the family is presented as an indispensable factor in the educational process, especially with regard to the monitoring of the performance of school activities. However, with the remote emergency education structured, nonface-to-face activities, carried out at home during the pandemic, the support of the family, especially in elementary school, became essential.

In this sense, among the teachers who participated in the research, with regard to the support received from families in the performance of school activities, they highlight that 39\% of the families are well involved in performing remote activities. As we can see in the excerpts:

I see in many families a support in following the studies of children providing an organization, a routine, this is fundamental at this time (P 7).

Parents strive to involve the children in the proposals (P 11).

Most have been trying to keep up with their children. (P 21).

I would like to share a greater involvement in activities, invest more time (P 18).

The statements highlight the importance of the family's participation in the educational process, as a significant contribution, particularly during remote teaching. Therefore, a possible partnership between family and school strengthens the relations between these two institutions. 
Other statements present this perception:

They're trying to do their best (P 166).

There is interest and responsibility on the part of families (P 133).

They're struggling to teach (P 111).

They're trying to develop their activities with their children as much as they can (P 28).

According to Monteiro (2020), this type of teaching may constitute a unique experience, establishing effective communication in the school community, including families, teachers and students. Therefore, building a welcoming and fostering family, in this moment of crisis that reaches everyone without exception. However, there are discourses that advocate that families are, in a way, experiencing at home, part of the daily routine, or even of the dynamics of teachers in the classroom.

Very close to the percentage to the support considered good, in the perception of the interviewees, the support of families in remote activities was partial in 38\% of cases, which is similar to regular or even medium. Thus, the statements express themselves:

Families are organizing as much as possible (P 101).

I believe you are capable and responsible for doing your homework (P 51).

Some are getting closer and supporting students (P 105).

Some have helped, but many do not have the necessary understanding to assist them (P 19).

They support within limited knowledge and by meeting deadlines (P 22).

In this context of social isolation, it is not always easy for families to assist their children in remote activities. The reports 
show that some do not have enough knowledge for this task. It is recorded that this research was carried out with teachers working in the Public School System and also with teachers from the Private Network. In fact, parents and guardians had to follow their children's school routine daily. It is known that this is not the only question. However, there are those who are on the margins of society, without access to technologies, the internet, and sometimes without the necessary food, because they are not working during this period of crisis. (Gonçalves, et al. 2020).

According to the research subjects, there are variations in the family support regarding school activities. However, the reasons for such attitudes were not found. The reports express differences between families, who support significantly and others who do not get involved. Similarly, there was a feeling of appreciation for the teaching work, and opposition to this reality at the same time:

Support varies between very present, concerned and involved parents and others who are not present in the different proposals (P. 77);

Not everyone's helping. Some parents claim that their children only want to do the activities with the teachers (P. 81);

Of some, full support and appreciation of my work, of course, with the exception of those who are against all this (P. 55);

Families really count on school (P.44).

Despite the possible partnership assumed by families, given the need for parents to participate in monitoring school activities, Santos (2020) helps us to reflect on this reality when he says: "The pandemic and quarantine are revealing that there are possible alternatives, societies adapt to new ways of living when this is necessary and it feels right to the common wellbeing" ( $p$. 29). The author also adds that such situations provide thinking of alternatives related to the way of living, producing, consuming and living together. 
Immersed in this scenario, according to the perception of the teachers interviewed, $13 \%$ of the families give little support to remote school activities in their daily lives with their children. The statements express themselves: "I realized that most families are not accompanying their children." They add: "The parents who help practically do everything for them." In this same perspective, 10\% of the families are not supporting their children, according to the data collected: "The reality for my students is none or scarce support".

In this reality, Monteiro (2020) highlights some pertinent issues involving the recognition of the significant and necessary relationship between school and family:

Are people really realizing the importance of the school institution in training children, adolescents and young people or are we creating yet another illusion in the context of the crisis? Will the school after this time receive appreciation and recognition for its space-time relevance or will the school remain just a place where parents "drop" their children for a few hours a day? Will we be able to build the much-desired work shared between school and families? (p.10).

It can be perceived from the statements of the interviewed teachers that the families are willing, to some extent, to collaborate in remote education at home in this pandemic period. However, the guidelines do not always reach everyone. Obstacles such as access to the internet prevent communication between families and school. However, we cannot take these data as a generalization, since different realities are in place, according to the social context of the students.

In the dynamism of everyday life, they often forget to give and recognize some meanings that are essential in the development of a person. This premise underlines one of the main impacts highlighted in this category. Thus, the approximation between parents and children was configured as an opportunity to strengthen affective bonds, and then perform school activities. With this, there was the inevitable sharing of physical and mental spaces in favor of the 
construction of knowledge. Actions that resulted in the recognition of the family role in the educational process. And consequently, an awakening arose to value the role of teachers, with the possibility of establishing solid partnerships between family and school.

\section{Impacts on interaction between teachers and students}

In this section, some collected answers allow us to reflect on the effects of the pandemic scenario on the relationship between teachers and students.

Children, adolescents and young people in school age and the teachers of these students have suffered the effects triggered by the new reality, because not all have the necessary conditions to maintain the school routine, which makes the adjustment to remote teaching more difficult. These are aspects that inevitably generate insecurity, anxieties and physical, cognitive and mental discomforts. In this context, it is believed that affectivity and physical contact were impaired, being one of the largest impacts perceived by the research teachers, as shown below:

We're doing directed studies; we have little contact with the children. From time to time we talk to them through the parent message app groups. I think that many consequences will be caused by this social distancing, especially for minors (P 2).

The emotional aspect was impaired (P 20).

The relationship has grown apart, even with the effort to use tools like email and Google Classroom. Maybe messaging apps and social networks got closer, but I found it personally safer not to use them. I like to keep that personal limit (P 30).

There is no emotional relationship. You practically work with numbers (P 36).

Only a few students interact in the group, so there is a distance between teachers and students (P 45). 
As can be seen, the deprivation of socialization was verified as a factor that influenced human relations. According to Schmidt (2018) community life, relying on each other, cooperating to survive is the basis that marks the human trajectory since the beginning of time. For hundreds of thousands of years, long before any trace of state or market, the pursuit of security in a hostile world has pushed humans to live in flocks, tribes, clans and all sorts of clusters, in which they shared affection, beliefs and values. Incomplete and inconclusive beings, humans are a social species. From life in small flocks to today's big cities, isolating means getting sick. In other words, community life meets human nature by fulfilling the permanent needs of conviviality and meaningful connections.

Through the answers, it is perceived that teachers are aware that affectivity has suffered damage with social distancing. Establishing emotional ties with students is a fundamental element for the teaching and learning process and is also a challenge from the psychosocial point of view, since it is necessary that the process is constructed and fed. According to Marchesi:

Emotional competence includes self-control, compassion, the ability to resolve conflicts, sensitivity to others, and cooperation (...). The affective development of well-being and its happiness, but also favors a positive attitude towards learning and a sensitive behavior in the face of the needs of others. It is therefore important that teachers are aware of their possibilities for intervention in this area and have sufficient competence to intervene satisfactorily (2008, p. 71).

What is most noted in these narratives is the willingness of students to be with mates, friends and teachers all together, living collectively, cooperatively, and producing knowledge. If we think about the university context, where to be present is so relevant, and something so simple at the same time, it became a routine that was impossible to replicate in the pandemic context. In this regard, Saviani and Galvão question whether remote teaching is capable of guaranteeing the expression of human life and collaborating with the emancipation of students, in view of social distancing. For the 
authors, it is not only about the physical distance, but also the quality of the knowledge and interactions that take place in this new format. In addition, remote education is impoverished by coldness and hampered by the impossibility of performing in-depth and quality pedagogical work (Saviani \& Galvão, 2021).

In addition to affectivity, social distancing also had an effect on the teaching and learning process, due to the challenging mission of teaching and evaluating what and how students are learning. These aspects can be observed in the excerpts of the answers:

Lack of personal contact and "face to face" makes it difficult to attend students who may be more difficult (P 23).

It impacts a lot the lack of feedback; I do not know how much the student really learns (P 38).

A new approach brings adjustments that need to be considered, including the discipline and behavior of students in the new environments (virtual classrooms) (P 13).

I believe that interaction does not happen enough (P 85).

In this sense, this expression "face to face" is rethought as a necessity for teachers. The presence and physical contact are such simple elements of the school routine and were taken from human life at that time. In this regard, Saviani and Galvão (2021) reflect whether remote teaching is capable of sustaining the expression of human life and promoting the emancipation of students, in view of social distancing. For the authors, it is not only about physical distance, but also about the quality of knowledge and interactions that take place in this format. This was also a concern of the participants in this research. Moreover, remote teaching is sometimes cold and hampered by the impossibility of performing in-depth and quality pedagogical work (Saviani \& Galvão, 2021).

In times of crisis like this, we human beings need to develop empathy, resilience and focus on the present moment to deal with the challenges and learn from the experience of the pandemic, 
because the return to the old normality will probably not happen, but the humanity will experience a new post-pandemic era, with no scheduled date, at least in Brazil. At this moment, it is worth thinking that there is still a "moment of critical disjunction that can involve destructive aspects, but which is also fundamentally a source of rebirth" (Morin \& Viveret, 2013, p. 33).

Rebirth, because, despite chaos, other individual or collective life postures can be created, which allow the development of resilience and empathy skills. As for the pedagogical practice promoted in this context, it is relevant to dialogue about the importance of developing abilities to adapt and be creative by disintegrating and reintegrating again, managing threats and weaknesses. This exercise shows that life, in adverse circumstances, is fleeting, as well as so many health and social crises that will affect humanity and the history of education, because we know that educating has never been an easy task. We must remember that the effects of neoliberalism have affected the world of work and, in the teaching profession, it would make no difference.

Another aspect that influences the relationship between teachers and students, more markedly today, are Digital Technologies (TD). These are not accessible to all school-age people and even to many teachers. There are different social and economic realities in Brazil and it is relevant to reassure that there is digital exclusion, mainly due to the differences between public schools and private schools and those who maintain them are different subjects. In addition to access to technological tools, it is necessary to go further, because not all schools offer technological training and not all households have a routine monitoring remote activities. Despite this disorder, some answers address remote education as an opportunity for new approaches in basic education and list positive aspects of this type of teaching, according to the following excerpts:

I believe the bond is even greater. In face-to-face time, I was able to show how my characteristics as a teacher were. Today, they understand what I am as a person and how I speak out. I've received many "I love you" and "I miss you teacher" (P 15). 
Increase in the relationship of mutual trust (P 29).

I realize that physical distance does not necessarily alienate teachers and students, I believe that the actions we take are relevant, so I believe that this relationship is even stronger in this period (P 39).

Students are closer because they see the teacher as a human being, in their environment "outside the classroom" and recognize the effort that teachers have made to completely reinvent classes. Students vibrate when something happens in class that is off script (cat passing in front of the camera) they feel more included, more participant (P 101).

It makes communication difficult, but they express their feelings more about what's going on (P 143).

From these excerpts, it is perceived that remote teaching is a possible part of human socialization. Teachers report that this format of teaching promotes affection and empathy, through the screens, aspects that minimize the physical distance between students and teachers. Talking about these subjective aspects, in the present days, feeds back these feelings and enhances the development of them, even in the face of uncertainty and crisis scenarios, such as the current one.

According to Mosquera and Stöbaus (2006), there are different points of view in various areas of knowledge that have considered that our emotional life is of great importance and that affection proposes an interesting journey to the world of emotions and feelings. This journey directly influences the process of teaching and learning, as well as how we relate to our working class, students and their families. This connection "is related to the space we live in, with the feeling of belonging, memory and collective meanings, beliefs, languages and values" (Cunha, 2006, p. 404). That is, the social bonds and the development of empathy of these teachers, (re) configures the ways of being a teacher and being a student, through subjectivities and shared interactions. 
Reports permeated by dualisms bare the hidden face of the pandemic experienced by many Brazilian students, who were left on the margins of a social system, which still benefits only one group of society. Some impacts of this category were thus identified, such as: the improvement of virtual school communication to counteract the distancing of students who did not have access to the Internet; mediated learning within easy reach, without having to leave home, simultaneously to the anguish of staying at home without being able to access classes or knowing their teachers; close ties with students who had access to technology, which is opposed to anguish and insecurity because they did not have contact with all students, only included as a number in school attendance. Afraid of not knowing them or even not meeting them at school when the pandemic ends.

\section{Final considerations}

The time has come to recapitulate the aim of this study, which was to analyze teachers' perceptions about the implementation of remote education and the effects on relationships with students and families during the Covid-19 pandemic. It was noticed that the voices of the interviewees echoed components inherent to the educational context in the modality of remote teaching. Initially, because it is an adverse situation imposed by the pandemic chaos established in the daily school, the factor of social inequalities was evident. Socially disadvantaged students were once again immersed in exclusion and limitations of their rights. In this group, contact with families was difficult and consequently school activities were developed remotely and returned to school teachers remotely as well. This was due to the lack of access to technology and at the same time, to the unexisting guidance from families, due to several factors, from the lack of knowledge to accompany their children, to the absence, due to in-person work, or the search for survival.

It can also be seen that students have been restructuring the construction of subjectivities, given the great challenges they are facing in this emergency teaching configuration. The loss of interest, lack of motivation and insecurity, in which they are guided by more individualized learning practices and the absence of social relations 
that the school provides, in addition to the inequality of access to technologies, are some of the feelings that permeate the context of the students, from the first days of adequacy and adaptation to this new situation, to this day. And that may be increased by the prolongation of social isolation that the pandemic required of all of us.

In this sense, one can shed light on affectivity in remote education as a possibility to reorganize education in this pandemic scenario, as well as in the ways of being a teacher and being a student, through subjectivities and shared interactions. Learning to deal with these emotions, in a process of self-knowledge, selfreflection and self-regulation are possible ways to help to modify the singularities faced in this context, allowing the emergence of a subject with possibilities to continue their learning process, through mutual understanding, mediation and collaboration between teachers and families.

Another important consideration is that this type of teaching was a viable alternative, through the need to continue the studies, but at the same time, it was also a challenge, taking into account the socioeconomic context of the families and the technical conditions of schools and teachers. The use of technologies was a favorable factor to mediate school practices during social distancing. It was beneficial and at the same time a limiting factor for those who do not have accessibility, and especially with regard to the effects on interaction and sociability between teachers and students and changes in the teaching and learning process, because learning and teaching individually and remotely has been a new situation for teachers and students.

Discussions about educational transformations during the pandemic allow us to reflect on the paths and obstacles experienced by Brazilian teachers and students. It is suggested that, when the pandemic by Covid-19 passes or even in the return of face-to-face classes, it is necessary to think about strategies to prioritize helping students who did not have access to remote studies, for example, learning labs. It is also important to think of ways to expand and reorganize the relationship between family and school. 
Therefore, thinking about the school, its mechanisms, practices and subjects, describing concrete situations and promoting reflection, is an indispensable condition for researchers of education nowadays. How to further the comprehensiveness of this crisis situation, as an opportunity to new-meaning the school as an important space to reduce the deep inequalities that our society faces.

\section{References}

Agência Senado. (12, Agosto 20). DataSenado: quase 20 milhões de alunos deixaram de ter aulas durante pandemia. 12/08/2020. https:// www12.senado.leg.br/noticias/materias/2020/08/12/datasenadoquase-20-milhoes-de-alunos-deixaram-de-ter-aulas-durantepandemia/\#conteudoPrincipal.

Bardin, L. (2011). Análise de conteúdo. São Paulo: Edições 70, 229 p.

Brasil. (1996). Lei de Diretrizes e Bases da Educação Nacional, LDB. 9394/1996. BRASIL- L9394 (planalto.gov.br)

Brasil. (2020). Portaria n 343, de 17 de março de 2020. Dispõe sobre a substituição das aulas presenciais por aulas em meios digitais enquanto durar a situação de pandemia do Novo Coronavírus COVID-19. Brasília, DF: Ministério da Educação, 2020a. http:// www.in.gov.br/en/web/dou/-/portaria-n-343-de-17-de-marcode-2020-248564376

Brasil. Constituição (1988). Constituição da República Federativa do Brasil. Brasília, DF: Senado Federal: Centro Gráfico.

Brasil. Instituto Nacional de Estudos e Pesquisas Educacionais Anísio Teixeira (INEP). (2021). Censo Escolar 2020: apresentação coletiva. Brasília, 2021. https://download.inep.gov.br/censo_escolar/resultados/2020/ apresentacao_coletiva.pdf .

Brasil. Ministério da Educação. (2020). Nota de Esclarecimento. O Conselho Nacional de Educação (CNE), considerando as implicações da pandemia da COVID-19. 18 de março de 2020b. https://abmes.org.br/arquivos/ documentos/CNE\%20\%20Nota\%20de\%20Esclarecimento\%20(1). pdf .

Brasil. Ministério da Educação. Conselho Nacional de Educação. (2020). Parecer CNE/CP n 5/2020. Aprova Diretrizes Curriculares para escolas durante a pandemia em 28 de abril de 2020. Disponível em: pcp005_20 (mec.gov.br) 
Comitê Popular Estadual de Acompanhamento da Crise Educacional CPEACE, (2020). Pesquisa Educação na Pandemia da COVID-19. https://cpers.com.br/wp-content/uploads/2020/08/PesquisaEducac\%CC\%A7a\%CC\%83o-na-Pandemia-da-COVID-19_ resultados_preliminares_pesquisa_II_coletiva.pdf.

Cunha, M. I. (2006). Pedagogia universitária: energias emancipatórias em tempos neoliberais. 1. ed. Araraquara: Junqueira \& Marins Editores, $143 \mathrm{p}$.

Flick, U. (2009). Desenho da pesquisa qualitativa. Porto Alegre: Artmed.

Ganda, D. R., \& Boruchovitch, E. (2018). A autorregulação da aprendizagem: principais conceitos e modelos teóricos. Psic. da Educação, São Paulo, 46, $1^{\circ}$ sem. de 2018, pp. 71-80.

Gil, A.C. (2008) Modos e técnicas de pesquisa social. 6. ed. São Paulo: Atlas.

Gonçalves, J. O., Miranda, M. F. O. de., \& Gonçalves J., E. (2020). Uma reflexão sobre a parceria da família e escola em tempos de COVID-19: Aspectos pedagógicos, econômicos e jurídicos. Revista Científica Multidisciplinar Núcleo do Conhecimento. Ano 05, Ed. 11, Vol. 06, pp. 141-154. Nov.2020. https://www.nucleodoconhecimento.com. br/educacao/economicos-e-juridicos

González Rey, F. (2017). Entrevista com Fernando González Rey. In: Campolina, L. de O. e Mori, V. D. (orgs). Diálogos com a teoria da subjetividade: reflexões e pesquisas. Curitiba: CRV.

Grandisoli, E., Jacobi, P. R., \& Marchini, S. (2020). Pesquisa Educação, Docência e a COVID-19. Pesquisa realizada pelo Centro de Síntese USP Cidades Globais do IEA sediado no Instituto de Estudos Avançados da Universidade de São Paulo.

Hermann, N. (2020). A aprendizagem da dor. Educação e Realidade, v. 45, p. e110033, 2020.

Leal, A. E. M. (2006). Construindo o conhecimento pela pesquisa: orientação básica para elaboração de trabalhos científicos. Santa Maria: Sociedade Vicente Pallotti.

Marchesi, A. (2008). O bem estar dos professores: competência, emoções e valores. Porto Alegre: Artmed, 2008.

Monteiro, S. S. (2020). (Re)Inventar Educação no Brasil em tempos de COVID-19. Revista Augustus (UNISUAM. ONLINE), v. 25, p. $237-$ 254.

Morin, E., \& Viveret, P. (2013). Como viver em tempo de crise. Tradução de Clóvis Marques. Rio de Janeiro: Bertrand Brasil. 
Mosquera, J. J. M., \& Stobäus, C. D. (jan./abr. 2006). Afetividade: a manifestação de sentimentos na educação. Educação, n. 1, pp. 123133, jan./abr.

Nóvoa, A., \& Alvim, Y. C.(2021). COVID-19 e o fim da educação: 1870 - 1920 - 1970 - 2020. Revista História da Educação (Online), v. 25: el10616.

Santos, B. de S. (2020). A Cruel Pedagogia do Virus. 2020. EDIÇÕES ALMEDINA, S.A. Coimbra- Portugal.

Saviani, D., \& Galvão, A. C. (2021). Educação na pandemia: a falácia do 'ensino' remoto. Universidade e Sociedade, v. 67, pp. 36-49.

Schmidt, J. P. (2018). Universidades comunitárias e terceiro setor: fundamentos comunitárias da cooperação em políticas públicas. led. Santa Cruz do Sul: EDUNISC.

Teixeira, N. F. (2015). Metodologias de pesquisa em educação: possibilidades e adequações. Caderno Pedagógico, Lajeado, v.12, n. 2, pp. 7-17.

Triviños, A. N. S. (1987). Introdução à pesquisa em ciências sociais: a pesquisa qualitativa em educação: o positivismo, a fenomenologia, o marxismo. São Paulo: Atlas.

Recibido: 03/08/2021

Aceptado: 08/11/2021 